NGTT Deel 54, Nommers 3 \& 4, September en Desember 2013

Van de Beek, Bram

Stellenbosch University

\title{
Reformed theology and politics
}

\begin{abstract}
The Reformed tradition has always been involved in political issues. In terms of this perspective the views of two major Reformed theologians, John Calvin and Karl Barth, are compared with opinions in early Christianity regarding the relation between Christians and politics. Theologians in the early patristic period kept their distance from politics. Calvin pleaded for sober involvement, while Barth eagerly calls for a prophetic participation in the public sphere. These differences may be interpreted as a natural development related to historical changes: from a persecuted community to the corpus christianum, and subsequently to the challenge of a perverse political ideology, and the call for a response in a new situation its defeat. From this perspective all three positions are understandable. However, being true to the Reformed call ad fontes one must conclude that Barth's theology is totally different from both that of early Christianity and the New Testament. This calls for a reconsideration of positions regarding the relation of church and politics.
\end{abstract}

\section{INTRODUCTION}

The Reformed tradition is considered a tradition dealing with everyday life, with work and public issues. For this tradition there exists no sacred sphere for religion, separated from the (never neutral) spheres of politics and the economy. Everything is related to God. In this article the views on politics and the state of two major Reformed theologians will be compared. John Calvin is found at the birth of this tradition, and special attention will be given to the influential last chapter of his Institutes. The other is Karl Barth, the most influential Reformed theologian of recent times. Because being "Reformed" was never aimed at being a specific tradition but rather at the reformation of the whole church by returning to the sources of early Christianity, the ideas of these two theologians will be compared with those sources. Early Christian texts and texts written by Calvin and Barth will first be discussed in chronological order, and then in reverse chronological order. After a reflection on the differences between both ways of reading, some conclusions will follow. ${ }^{1}$

\section{EARLY CHRISTIANITY}

Hugo Rahner published an overview of early Christian texts on Christian attitudes towards the state (Rahner 1961). ${ }^{2}$ In this overview three distinct aspects of public theology come to the fore (all of which have their roots in the New Testament), namely prayer, obedience and a limitation on the claims of government.

1 For the comparison, a few classic core texts of the authors were used. A full elaboration of the theme would, of course, require investigations into their other works and contemporary authors, and taking into account secondary literature. That is impossible in an article. It would require a full monograph. However, precisely this focus on core texts highlights the differences and clearly shows the changes in theology.

2 Readers who want to easily access many patristic texts on the topic in one volume can refer to Rahner's anthology, though the texts mentioned in this work are by no means exhaustive. Those who want to do further research can, of course, find the texts in editions of early Christian writers. 


\section{Prayer}

Early Christians used to pray for government. Many early Christian writers mention that the faithful pray for the emperor. This is done in line with Paul's exhortation in his first letter to Timothy: "I urge, then, first of all, that requests, prayers, intercession and thanksgiving be made for everyone - for kings and all those in authority, that we may live peaceful and quiet lives in all godliness and holiness" (1 Tim. 2:1ff.). Christians prayed for a good administration so that justice may rule in the empire (Clemens, Letter to the Corinthians 60:4 - 61:1: Rahner 1961:40; Tertullian, Apology 30: Rahner 1961:46). They did this because the peace of the empire was, of course, the peace of Christians as well (Tertullian, Apology 31: Rahner 1961:49). They, therefore, not only prayed for righteousness, but also for the power of Rome, so that its enemies would not destroy the Roman peace. For this reason they also prayed for a brave army (Tertullian, Apology 30: Rahner 1961:47).

The Roman Empire was the guarantor of a quiet life, and not just with regard to the then current reality. For some authors it formed part of their eschatological religious convictions. In his letter to the Thessalonians, Paul refers to the lawlessness that will come to "the one who holds him back" (2 Thess. 2:6ff.).Many have speculated about what or who this "onewhoholdsback" might have been. Regardless, Tertullian was convinced that it was only the Roman Empire that prevented the world from falling into the abyss of chaos at the end of time:

For we know that a mighty shock impending over the whole earth - in fact, the very end of all things threatening dreadful woes - is only retarded by the continued existence of the Roman empire (Apology 32: Rahner 1961:49 - 51).

The Roman Empire was seen as a blessing from God, given on behalf of his people. Therefore, Christians prayed for the wellbeing of this empire. Even though some emperors were brutal dictators and claimed to be gods, the Roman Empire was preferred to the chaos that would ensue should it fall. Only the devil wants to deconstruct society into chaos (Irenaeus, Against Heresies V,24,2).

The emperor was the heart of the empire. Christians, therefore, not only prayed for the empire but for the emperor himself. He was seen as the embodiment of the pax Romana, and this warranted their prayer for his health and life (Tertullian, Apology 30: Rahner 1961:47). Thus, the Roman emperor was intrinsically important in the early Christian faith, not only since Constantine but long before Constantine's reign.

In Scripture, Peter's epistle refers to Christians as priests (1 Pet. 2:5,9). Origen did the same, and applied it in a very specific sense: as priests, Christians offered a particular service to the empire, namely priestly intercession (Against Celsus 8,73ff.). Priests were exempt from military service in the Roman Empire, as they supported the state in a different way, namely by their intercessions to the gods. Origen argued that the Christian community constituted a priesthood in the service of the state, replacing the priests of the old gods of Rome. By their intercession and life, Christians are the salt of the earth (Origen, Against Celsus 8,70: Rahner 1961:68). Again, this was not written in the time of a Christian empire, but during a time of persecutions wherein Origen's life ended. Christians were seen as the soul of the body of society (Letter to Diognetus 6).

\section{Obedience}

From this perspective the Christian call for obedience to the emperor does not come as a 
NGTT Deel 54, Nommers $3 \& 4$, September en Desember 2013

surprise. The church fathers often quoted Jesus' injunction to "[g]ive to Caesar what is Caesar's" (Mt. 22:21; Mk. 12:17; Lk. 20:25; cf., for example, Justin Martyr, Apology I,17: Rahner 1961:42; Hippolyt, Commentary on Daniel III: Rahner 1961:53). They also referred to Romans 13, where Paul calls for obedience to the emperor (for example, Origen, Commentary on Romans IX, 26: Rahner 1961:58). One finds not the slightest indication of revolutionary ideas among Christians in the first centuries. Though they sometimes suffered greatly and many of them were martyred, Christians were obedient to the state (Athenagoras, A Plea for the Christians 4; Theophilus of Antioch, To Autolycus I, 11: Rahner 1961:44). At most Christian writers appealed to the laws of the Roman state in their defence of fellow Christians.

There are several reasons for this call for obedience. First, it would have resulted in even more hardship should they have revolted against a power so much stronger than themselves. If one caused trouble for the Roman state, one would have realised that it did not carry the sword for nothing (Rom. 13:4). Athenagorsas writes in his plea to the emperor:

[We] pray for your government, that you may, as is most equitable, receive the kingdom, son from father, and that your empire may receive increase and addition, all men becoming subject to your sway. And this is also for our advantage, that we may lead a peaceable and quiet life, and may ourselves readily perform all that is commanded us ( $A$ Plea for the Christians 32).

Second, the stability of society was in itself a great blessing. The hardship of revolution and civil war was much worse than the injustice and arbitrariness suffered at the hands of Roman procurators - better an imperfect law than no law at all. Discord was an evil to be avoided by Christians and the unity of human society a good to be pursued (Tertullian, Apology 30: Rahner 1961:44). A final argument, however, was that disobedience would strip martyrdom of its glory. If Christians were to be put to death because they did not obey the law, they would be rightly punished. However, if they were unjustly sentenced, they gave their lives as blameless sacrifices, the blood of which became the seed of the church (Origen, Commentary on Romans IX: Rahner 1961:60 - 62).

The above views implied that the laws of the state were good, which is precisely what Origen argued. When the apostles declared that Christians should "abstain from food sacrifices to the idols, from blood, from the meat of strangled animals and from sexual immorality" (Acts 15:29), one might conclude that murder, theft, and other crimes were allowed, since these are not mentioned. Origen argued that the latter crimes warranted no mention because they were already forbidden by public law. Only what is not in the laws of the state was added (Origen, Commentary on Romans IX, Rahner 1961:60 - 62). These laws prevent people from committing crimes and, therefore, they were seen as precious gifts from God.

This then is at the core of the call for obedience: the government as such is given by God. Paul expresses this opinion in his letter to the Romans (Rom. 13:1) and it is supported by later generations of Christians (Clemence of Rome, Letter to the Corinthians 61; Irenaeus, Against Heresies V,24,1; Tertullian, Apology 28: Rahner 1961:44 - 46). It applies to a non-Christian or even an unjust government. It is said about the reign of Claudius, who was emperor in those days - a wicked emperor who was outdone in evil deeds only by his successor, Nero. It thus did not matter whether a government operated justly. Government itself was a gift from God and one day God will call on its officials to account for their deeds (Justin the Martyr, Apology I,17: Rahner 1961:42). It was not the prerogative of the governed to drive them from their 
NGTT: Oopbron - http://ngtt.journals.ac.za

thrones. The root of Christian obedience to the government was the belief that it was God's government (Origen, Commentary on Romans IX: Rahner 1961:60).

\section{Limitation}

Precisely because the government is subject to God's government, Christians refused to render ultimate honour to it. Government is subservient to God, who is the supreme Ruler and, therefore, no government could be absolute. Still, it had to be honoured, albeit within its limitations as a created and ordained entity. Government is believed to be human, not divine. Therefore, Christians could not worship the emperor as Deus ac Dominus. They were willing to obey him in everything, but not if he required worship and made claims that were reserved for God alone (Theophilus of Antioch, To Autolycus I, 11: Rahner 1961:42 - 44; Tertullian, Apology 28: Rahner 1961:44; Hippolyt, Commentary on Daniel III, 25 - 31: Rahner 1961:52 - 56).

Furthermore, should the Roman government require submission to and the worship of its own gods, this would be an insult to these gods. For if the worship of these gods was dependent on the will of the emperor, it implied that the authority of the emperor was a higher authority than theirs. Tertullian joked about this compulsion of the emperor to demand the worship of his gods: the emperor was indeed a higher authority than they, for a living human has higher authority than a dead, nonexisting god (Tertullian, Apology 28: Rahner 1961:44).

Only a God who convinces people to honour the government can be a true God. God cannot be dependent on the power of government. Any government that makes claims to the contrary is a false government.

It was this refusal to acknowledge the government as divine that brought Christians into conflict with the Roman Empire, until Constantine acknowledged the truth of Christian public theology in the beginning of the fourth century. However, when his successor, Theodosius, declared Christianity the official religion of the Roman Empire, he turned the above Christian insights upside down: now the emperor urged people to worship the Christian God. In terms of Tertullian's comment about the emperor defining who the true God is (cf. Tertullian, Apology 30: Rahner 1961:46), this could however be seen as blasphemy, as Theodosius made God dependent on his own edict.

\section{Christians in government}

Thus far only Christians and their relationship to government have been considered. In addition, one has to also consider Christians in and part of government. The texts selected by Rahner do not give any information about this, which does not necessarily mean that such texts do not exist. They do, the most explicit being a section of Contra Celsum. After his discourse against the emperor's claims to divinity, Origen proceeds to discuss the challenge by Celsus to Christians to participate in the Roman administration. He suggested that if they have so much critique against the government's decisions and societal behaviour, Christians should try and do better.

It might be expected that Origen would accept such a challenge since Christians have such high regard for the government as God's gift; however, his response to Celsus was a refusal of the offer to participate in government. When Christians have leadership capabilities, Origen stated, they should use them in the church, not in government (Origen, Against Celsus 8,73 75). Precisely because they have a higher task as priests, they cannot neglect their calling of praying and thus they will not become administrators, judges or government officials. 
NGTT Deel 54, Nommers $3 \& 4$, September en Desember 2013

Someone in the service of the reign of Christ cannot serve the earthly reign of the emperor except by praying for the latter's wellbeing. Should Christians stray from this conviction, they will be denying the very Lordship of Christ. If one is called to the service of the supreme Lord, one is not allowed to accept a call of a lower servant and disregard one's ultimate calling. Even the Apostolic Constitutions of the end of the fourth century, when Christianity was state religion, still prohibit Christian office bearers to enter the service of the emperor, especially in the army:

Let a bishop, or presbyter, or deacon, who goes to the army, and desires to retain both the Roman government and the sacerdotal administration, be deprived. For the things of Caesar belong to Caesar, and the things of God to God (Apostolic Constitutions 8:47,83).

Another argument against participation in civil service was that the state could only exist on the strength of its coercive power. If need be, it could punish people with violence and ultimately by putting them to death - at the time either by a death sentence or by conscription into the army to defend the state. However, according to early Christians one may not take another's life as God alone rules over life and death. Therefore, the Traditio Apostolica forbade both a judge as well as a soldier to become a catechumen (16:9 - 11). Early Christian authors of various contexts and temperaments such as Origen (Contra Celsum 8,73), Hippolyte (Traditio Apostolica 16:9 - 11) and Tertullian (On the Chaplet) argued against the conscription of Christians into the army, for "we are peacemakers - pacifici" (Origen, Commentary on Matthew 26:52: In Mattheum 102, Migne, PG 13, 1752). The glory of the victories of the emperor's army was anointed with the tears of wives and mothers of the killed opponents (Tertullian, On the Chaplet 12) - who may even have been brothers in Christ, "for Christ is also among the barbarians" (On the Chaplet 12). Therefore, Christians serve in "another national organization, founded by the Word of God" (Origen, Against Celsus 8, 75).

\section{Calvin's institutes}

The last chapter of Calvin's Institutes (with little change in subsequent editions) has had a profound influence on Reformed political thought - although usually in interpretations that suited later theologians and politicians. If one compares Calvin's position to that found in early Christian thought as described above, one finds many similarities. Calvin stresses the importance of prayer for the government. He also believes that government is a gift from God and that one should obey its laws. Against the radical Reformation, Calvin held that Christians should not be revolutionaries but decent citizens (Inst. IV,7). He also agrees with the church fathers that God should be obeyed, and not humans, if government claimed greater honour than is owed to God (Inst. IV,32). Therefore, before noting the differences between the views of Calvin and the church fathers, one must carefully note that their overall frame of thought was not all that different from each other. Like the church father, Calvin opposed (two) false attitudes toward the government:

On the one hand, frantic and barbarous men are furiously endeavouring to overturn the order established by God, and, on the other, the flatterers of princes extolling their power without measure, hesitate not to oppose it to the government of God (Inst. IV. 20.1).

Nevertheless, there are also some differences. Though Calvin is reluctant to accept resistance against a wicked government, he considers the possibility that lower levels of government may oppose the national or imperial government and may even overthrow it (Inst. IV.20.31). 
NGTT: Oopbron - http://ngtt.journals.ac.za

This is an interference in political affairs that was absent in early Christian thought. It is also different from the perspective of the church fathers for whom earthly affairs were accepted as God's providence, even if these implied suffering and - ultimately - death. The Letter to the Hebrews states from this perspective: "You joyfully accepted the confiscation of your property, because you knew that you yourselves had better and lasting possessions" (10:34). This is different from princes who replace an unjust king. In this way Calvin is more open to a Christian involvement in political affairs. However, one must not lose sight of the fact that, despite what he says here with regard to lower princes, it does not overrule or replace Calvin's continuous stress on due obedience and submission to the government, even if the latter is wicked (Inst. IV.20 and $22-32$ ).

Besides this, Calvin states that government should further true religion and oppose false religion (Inst. IV.20.2). This could be interpreted as being in line with early Christian thought for it means that a government should not make religious claims and should oppose any religion that does not recognise the difference between God's divine rule and the rule of human government. A false religion is one in which created entities - even those created by king and government - are seen as divine. Calvin is very much aware of the limited character of the state. It is temporal and its organisation depends on specific circumstances and contexts. Like Tertullian, he thinks that worldly government is suited for the present (Inst. IV.20.2). This is Calvin's primary view. Nevertheless, in his idea that government should promote true religion something more is found. Governments are not only called "to foster and maintain the external worship of God", but also "to defend sound doctrine and the condition of the Church" (Inst. IV.20.2). In Calvin's own context this implied a call upon the government to promote the Reformed faith against Roman usurpation and especially to refute radical political religion as propagated by the Anabaptists. The fact that government should promote true Christian faith is not a totally different position than that of church fathers, but it does entail a further element. However, one should not overemphasise this for Calvin himself explicitly states:

I no more than formerly allow men at pleasure to enact laws concerning religion and the worship of God when I approve of civil order which is directed to this end, viz., to prevent the true religion, which is contained in the law of God, from being openly violated with impunity and polluted by public blasphemy (Inst. IV.20.3; see also Inst. IV.20.9).

A third difference between Calvin and the church fathers concerns the involvement of Christians in politics. Calvin's perspective on Christians as subjects governed by the state is similar to that of the church fathers. Their theological framework is similar: the state is something different from the church and Christians should obey the government by being a servant of God. However, one does not find ideas in Calvin's work similar to that of Origen, namely that Christians should not be part of the administration of government and are, therefore, not allowed to be judges or to serve in the army. On the contrary, in this world the army is a necessary instrument of government (Inst. IV.20.11). The administrators of Geneva belonged to the same congregation where Calvin practised his ministry. They were Christians - as were almost all people in Western Europe at that time. Since the time of Constantine it was almost impossible to have a government comprised of nonChristians, and this was most certainly the case in sixteenth century Europe. This also had consequences for mutual relations between Christians. Unlike Paul (1 Cor. 6:1 - 11), Calvin condones court cases between Christians if this happens in a proper way and with the right attitude. Calvin, therefore, had to reinterpret Paul (Inst. IV.20.17-21). 
NGTT Deel 54, Nommers $3 \& 4$, September en Desember 2013

This is an example of how Calvin had to adapt his theology to his context. Nevertheless, he did so with moderation and continued to uphold the idea of Christians being governed subjects even if he did not reflect much on the tasks and responsibilities of Christians within government.

In conclusion, one sees in Calvin's Institutes a slight adaptation to new circumstances of Christian thought on public affairs, because he admitted participation in the government and even revolt to a tyrant by lower governments. This was, however, reluctantly done and did not put Calvin on the frontline of new opportunities and challenges on the road to a just and Christian Europe. Calvin is writing theology, and politics have only his heart if it is for the well being of the church. The state is a limited and relative earthly body, and dealing with it is for Calvin almost an appendix to his wonderful reflections on God's Providence, on Christ, and his Spirit.

\section{KARL BARTH}

It is precisely because the political theology of Calvin (and other Reformers) is not very much elaborated that Karl Barth enters the discussion. "It must be strongly emphasized that on this point they do not by any means tell us all that we might have expected" (Barth 1939:3; 1938:4). ${ }^{3}$ If Christians are mere subjects, they will conform to the will of their rulers. However, when Paul speaks about being subservient to the government, he does not mean that we are mere obedient subjects. Being subservient implies taking responsibility for the government (Barth 1939:34 - 36; 1938:21). For a Christian this means seeing politics in the perspective of Christ. Barth criticises Calvin for not keeping to the fullness of Christ when dealing with the state:

We can neither overlook nor take lightly this gap in the teaching that we have received from the fathers of our church - the lack of a gospel foundation (that is to say, in the strictest sense, of a Christological foundation) for this part of their creed (Barth 1939:6; 1938:6).

It seems as if everything Calvin so enthusiastically wrote on being in Christ and being led by his Spirit in preceding parts of the Institutes is forgotten when he writes about the political responsibilities of Christians. When reading the latter, it seems one is a traveller in a distant land (Barth 1939:4; 1938:4). Therefore, the Institutes end with a chapter that does not touch the heart and does not challenge us toward a renewal of society.

Barth wants to fill this gap. Although Barth might do so from a different political perspective, he shares the conviction of Abraham Kuyper, who wrote that "there is not a square inch in the whole domain of our human existence over which Christ, who is Sovereign over all, does not cry: 'Mine!' " (Kuyper 1930:32). Politics does not constitute a neutral space apart from Christian faith. Faith concerns all of life, and politics are an essential part of this. Human life always has political elements. Christian life, therefore, also has political elements, for no part of reality falls outside the power of Christ. He is Lord of the world (Barth 1946:12). Therefore, Christians are called to carry out their responsibilities in society and in politics in ways that bear the signs of his Lordship (Barth 1939:77 - 81; 1938:42 - 44). That was, according to Barth, even more true in his own time when a political system tried to govern to the benefit of the worst

3 The translation of the title of Barth's brochure as Church and State does not really do justice to the German Rechtfertigung und Recht. I, therefore, also supply references to the German original. 
NGTT: Oopbron - http://ngtt.journals.ac.za

form of paganism. It was a time when questions regarding the relationship between faith and politics were raised with new urgency (Barth 1939:8; "in je ganz neuer Eigenart und Schärfe", Barth 1938:7).

Barth is thoroughly aware of the fact that the state will never be the kingdom of God (1939:38 - 40; 1938:22f.). On this point he is fully in line with Calvin, who also made a clear distinction between limited human governments and the eternal reign of God in Christ (Barth 1946:5f.). Even so, Calvin looked at human governments from the perspective of general providence wherein his Christology did not play a role. Barth considers the state to be an analogy for the coming reign of Christ (Barth 1946:8ff.). There is a similarity (Gleichung) and politics have a Gleichnisfähigkeit to God's kingdom (Barth 1946;22f). Of course, in Barth's theology one should not reverse the sequence. One must reflect on the Lordship of Christ first and then look at government from this perspective - not the other way around (Barth 1946:23). Only from this perspective and direction does the church know what the meaning of government is and how justice should be accomplished (1939:46 - 50; 1938:28 - 30). Without faith, government is blind (Barth 1946:5) and could arbitrarily adopt any ideology to justify its decisions. Such arbitrariness not only opens the door to any kind of ideology, but as a consequence often leads to oppression and exclusion. Only confessing the One Lord, Jesus Christ, prevents a government from becoming its own end (Barth 1939:71 - 73; 1938:39 - 40). The government is an institution given by the only Lord of the world on behalf of humans (whom He also created). According to the analogy of faith, such an institution should, in its own limited way, reflect the glory of God's justice.

Barth agrees with the church fathers and with Calvin that government is an institution of God. If so, Christians should not be mere passive subjects but responsible actors on the political stage. It is in submission to the government as a God-given institution that Christians are called to take coresponsibility (Mitverantwortung, Barth 1946:13). Christians are called to express their faith in all spheres of life. Reformed Christians, in particular, should know that politics are fully part of life and that they cannot escape their political responsibilities. On the contrary, they should be eager to participate in making society a sign of God's just rule (Barth 1946:24). Barth accuses the Reformers of not being consistent in their confession of the Lordship of Christ. In addition, he also regrets that Romans 13 and the whole New Testament were not more specific "about what is, and what is not to be understood by these particular political duties towards the State which are to be expected of the Church" (Barth 1939:73ff.; 1938:40). For Barth the political responsibility of Christians is an expression of their faith in the One Lord, Jesus Christ. Barth himself extensively demonstrates what the character of Christian politics should be in following Christ (Barth 1946:25 - 33), though he says that characteristics of humanity such as justice, freedom, care, responsibility, service, mercy, et cetera, are only examples of the Christian's political calling (Barth 1946:33).

Barth is aware that this responsibility is exercised within the confines of life on earth: the fullness of love and peace has not yet come (Barth 1946:5). There is evil and the powers of darkness are still at work. One has to remain vigilant of the countermovement of powers that want to destroy God's creation and resist it. Such resistance requires the power of weapons and other instruments of violence such as penalties and prison. Christians cannot be so idealistic as to reject all use of weapons. This will amount to confusing the kingdom of God and the analogous world government. The latter cannot do without weapons. "Human law needs the guarantee of human force" (Barth 1939:75; 1938:41). For Barth, therefore, it was never a question of whether the Swiss had to have an army to protect it against the threat 
NGTT Deel 54, Nommers $3 \& 4$, September en Desember 2013

of Nazi Germany or whether Christians should wholeheartedly participate in this army or not (Barth 1939:76; 1938:41ff.). He was convinced that they should be the first to take up arms against an evil regime so that the government might reflect - in its own limited way, of course - the justice of God.

Barth is not reluctant to adapt Christian public theology to changed circumstances. He draws from the early Christian position that the government is God's government. In the analogy of faith, the government reflects God's just rule; and Christians are fully, and enthusiastically, involved in it. "The light which falls from the heavenly polis upon the earthly ecclesia is reflected in the light which illuminates the earthly polis from the earthly ecclesia through their mutual reflection" (Barth 1939:61; 1938:34). Christians take on their responsibility even if at the cost of life itself - maybe on the battlefields where many young men died on behalf of a righteous society or in prison, as in the case of Bonhoeffer.

\section{IN REVERSE PERSPECTIVE}

Thus far a historical perspective on the relationship between Reformed faith and politics has been discussed in chronological order, that is, the usual way of treating historical developments. Ideas are adapted to changed circumstances over time, and implicit consequences appear over time. We can come to an understanding of changes in this manner and can come to value them. Reformed Christians will appreciate this approach even more because being Reformed means being conscious of semper reformanda. Christian faith cannot be fixed in the formulas and structures of a specific time or place since it refers to a living reality as the work of the living God through his Spirit. To confine it will amount to making faith into an idol. Therefore, although one cannot return to the situation before Calvin or Barth, Christians have to develop their thought further, in new contexts and with further critical awareness of the consequences that are implied in the confession that Jesus is Lord.

However, we can also approach the issue from a reverse perspective: from Barth via Calvin looking back to the church fathers and subsequently to an interpretation of Scripture. This is not the usual approach followed in modern critical research: faith seeking understanding is faith seeking historical understanding. However, this begs the question of what historical understanding is: whether it is necessarily an understanding according to historical developments or whether it could also be grounded in the perspective of historical sources or roots. It is precisely the latter that the Reformers intended. It was not their aim to adapt Christian theology to changed historical circumstances but to restore it from aberrations that occurred during historical developments. Their slogan was "back to the sources" (ad fontes). Reformation was needed not because of new circumstances but because the church strayed from the truth. Theology should return to its beginnings. The church is semper reformanda because she must continuously be critically reflected upon from the perspective of her sources and because she is inclined to always make compromises with the world.

From this reverse perspective we begin with Barth, who considers the government to be an analogy for the kingdom of God. It should therefore be an expression of righteousness, and Christians should take responsibility for contributing to such a society and to defend it when it is threatened. This seems obvious to present-day Christian theology: Christians strive toward justice and will promote it as far as they are able to do so.

However, one then has to wonder why the Reformers were so reticent about political 
NGTT: Oopbron - http://ngtt.journals.ac.za

affairs. Why does Calvin's last chapter in his Institutes pale in comparison to the splendour of Rechtfertigung und Recht and Christengemeinde und Bürgergemeinde? One cannot suggest that participation in political change according to the ideals of the kingdom of Christ was not yet on the mind of Christians in the time of Calvin. On the contrary, this mindset existed everywhere around him, especially in the radical Reformation. Maybe its proponents were too radical, but still, this does not explain the lack of involvement in the implementation of the church's calling to bring about justice and righteousness. In fact, it should have challenged Calvin to develop a more balanced public theology that could have been implemented for the sake of a just and peaceful society. Yet something prevented Calvin from entering into a discourse on a theology of political involvement in the same way Barth did. It would be possible for Barth to blame Calvin for this, but critical theology has to investigate why Calvin did not travel the road Barth wanted him to.

Searching for an answer to this question one comes close to the very heart of the Reformation: ad fontes. The call to return to early Christian thought, beginning with the New Testament, plays a key role in Calvin's conclusions. He does not enter into the issue of political changes. His uneasiness is palpable when he does venture a step further, in opposing a wicked regime. It is precisely his sources that prevent him from doing so and that keep him conservative in political affairs.

One should, therefore, turn to Calvin's sources and wonder why they do not call for societal changes. This is not an anachronistic question, because political change was present at the very beginning of Christianity as well, especially where it originated in Palestine, with the Jewish war as its culmination point. The accusations and charges levelled against Jesus to the Roman governor by his opponents fit quite well with such an atmosphere. One may then well ask why Christians did not opt for working towards active political change from the very beginning.

To review the answers given above: the very practical consideration that one would have been confronted by harsh and brutal repercussions may call on Christians to oppose these. However, this does not disclaim the ultimate truth that Christians have a freedom that exceeds all forms of worldly freedom, and that the pursuit of the latter would disclaim the confession of freedom in Christ. Such distinctions are precisely the starting point of Calvin's reflections on politics (Inst. IV.20.1).

Early Christian thought regarding politics is succinctly expressed in Jesus' reply to Pilate: "My kingdom is not of this world" (Jn. 18:36). Of course, this can be seen in a Gnostic or other world denying ways, which does not sit comfortably with the gospel that begins by speaking about creation as Christ's own (Jn. 1:112). Nevertheless, it cannot be interpreted as merely meaning "not based on the methods of the world" (that is, violence). Certainly this is implied as well, but this view can only be held if Christ's kingdom is from a qualitatively different order than the governments of this world. If Christ's kingdom was of this world, his servants would have resisted his arrest (Jn. 19:36). That is the way kings operate. Barth is correct in saying that, at the very moment one accepts political responsibility, one must be prepared to join the army. It is the way in which governments operate in this world: no state can exist without an army (unless a small state is kept secure by a larger, more powerful ally or neighbour). Barth's political theology unavoidably has as a consequence that a Christian - en route to destroy an enemy that is willing to further the ultimate ends of evil - may be flying an aircraft carrying a nuclear bomb. A Christian is not only allowed to do so, he or she would be called to do so. 
NGTT Deel 54, Nommers 3 \& 4, September en Desember 2013

If someone does not want to accept this consequence, all talk about political responsibility is futile.

Asking whether Christians should be in the army is this the same as asking whether Christians should be in politics. Barth's answer is clear: "Yes." The answer of early Christian theologians was also clear, but a clear "No" (cf. Van de Beek 2006). Calvin avoids a definite answer when dealing with Christians as subjects of governments even while being conscious of Christians serving as magistrates. He keeps the early Christian theological framework but omits the conclusions that were clear to them. Calvin himself is reformandus - but one could ask whether he is reformandus in the direction of Kuyper and Barth, or in going back to the sources of Christian theology. Putting the question in perspective of the early Reformation, the answer is: ad fontes. Calvin exemplifies that it is difficult to reform the church and to be a Reformed theologian, and thereby for the church to be semper reformanda.

Regarding this Calvin does not differ very much from his later Roman Catholic colleague Hugo Rahner, after Rome implemented a reformation in its own way. In his overview of early Christian texts on public theology, Rahner in his anthology collected only those passages that fit into present day postConstantinian theology, both in the case of the Reformation and of Rome. He omits the Traditio Apostolica and texts on pacifism by Tertullian and Origen. He even ends the long exposé of Origen in response to Celsus just before Origen reaches the apex of his discourse: that Christians should not join government administration because they are administrators of a more supreme nation. Rahner and Calvin still have a sense of the critical power of early Christian thought, which Barth has lost, but they do not follow the church fathers to the very end. The ultimate consequence of this change is that Christians do not end in defenceless, vulnerable love, but in the army instead, acting according to the directions of adrenaline and testosterone - for these make the army powerful, as it should be according to the rulers of this world.

\section{GOD'S SERVANT AND THE BEAST}

If both Barth and the church fathers conceive the government to be a God-given institution, one must then distinguish between their positions. For Barth government is an analogy for the kingdom of God. In some way it reflects the justice and peace of God's eternal reign. Yet for the church fathers government is a temporal gift - for the time being - until the final tribulations come and the world ends. The kingdom of God will come as a resurrection from death. This does not mean there is no positive relation between this world and the world to come, but it is the relation of a seed to a plant. It is not different from the relation of earthly life to the life of the resurrection as Paul speaks about it in 1 Corinthians 15. The seed is not a lower level analogy for the plant, but the germ with the promise of what is to come, and the life to come will follow in the wake of the death of the seed. Christians participate in God's life in Christ, but they do so under the conditions of this world: bearing their cross. They are happy when they are in good health and not persecuted. They thank God for such gifts. But they know that one day this life will end and their being in Christ will only be fulfilled when this earthly life has passed away. They hope that the transition will not be difficult - but if so, it cannot be compared to the glory that will be revealed.

Earthly structures, including governments, are similar. It is a gift if there is justice and peace, and Christians pray for this and thank God for it. But if it is not to be, the sufferings of this world cannot compare to God's kingdom. We also know that one day all earthly institutions 
NGTT: Oopbron - http://ngtt.journals.ac.za

will cease to exist. We only hope and believe that the time of tribulation will be limited on behalf of the elect (Mt. 24:22; Mk. 13:20). The government keeps earthly affairs in good order just as food and drink support the body. It is God's servant in that way: serving limited earthly life that will one day come to an end.

If the difference between earthly affairs and heavenly life are taken into consideration, it is no wonder that Calvin's language about the government is bleak compared to his discourse on the life in Christ, as Barth noticed. There are many poems about flowers, but few about the seed from which they grew. Government just helps to keep the seed dry - until one day it must fall in soil. It is the governments of the world that will introduce the chaos of Armageddon, for governments belong to this world that has fallen into sin.

Here can again be found a similarity with individual life, for human structures and human life cannot be separated. In the limited conditions of earthly life we do good, more or less - and it is a pleasure if it is indeed "more". But, compared to the ultimate requirements of the kingdom of God, we can only join Paul in saying:"I know that in me, that is, in my flesh, there is no good." Being in Christ we are glorious; in ourselves we are not good.

The government is a similar case. If it is about limited earthly life, it is more or less just and we can be happy if there is "more" of it, and it to an extent prevents total chaos in the world. This is a gift from God - again, for the time being. But if it is about the absolute peace and justice of God's kingdom, there is no such good in government. That is the difference between Romans 13 and Revelation 13. It is not the case that Romans 13 is about a relatively just government and the author of Revelation is confronted with evil incarnate in the emperor. Barth makes a distinction between a good and a wicked administration, between government and tyranny, between a state according to Romans 13 and according to Revelation 13 (Barth 1946:16). By doing so, he takes into account neither the different theological perspectives of the two chapters nor historical reality. The later emperors of the Julian house in the time of Paul were no better than the Flavians in the time of Revelation. It is only the perspective of both writings that makes the difference: Romans speaks about earthly conditions and the relative circumstances of present society; Revelation views everything sub specie aeternitatis - from a heavenly perspective (Rev. 4). According to this view one has to say that no good is to be found in government, that it is a beast from the abyss.

Barth too easily makes a positive comparison between government and the kingdom of God. A government can become the beast, according to him (Barth 1939:11; 1938:8); it can become demonic (1939:21 and more extensively, 30; also 1938:14, 18). He does not take different perspectives into consideration: one of living in this world that is subject to death and the other of the new creation in Christ. Because Christians belong to the latter, they must resist the temptation of making agreements (and thus analogies) with the former.

\section{BiBLIOGRAPHY}

Barth, K. 1938. Rechtfertigung und Recht. Theologische Studien 1. ZollikonZürich: Evangelischer Verlag. Barth, K. 1939. Church and State. (Translation of Rechtfertigung und Recht). London: Student Christian Movement.

Barth, K. 1946. Christengemeinde und Bürgergemeinde. Theologische Studien 20. ZollikonZürich:

Evangelischer Verlag.

Calvin, J. 1845. Institutes of the Christian Religion, tr. Beveridge, H. Edinburgh: Calvin Translation Society. Kuyper, A. 1932. Souvereiniteit in Eigen Kring. Rede ter Inwijding van de Vrije Universiteit, den 20sten October 
NGTT Deel 54, Nommers $3 \& 4$, September en Desember 2013

1880 Gehouden, in het Koor der Nieuwe Kerk te Amsterdam. (Sovereignity in Own Circle. Address at the Inauguration of the Free University, 20 October 1880. Held in the Choir of the New Church in Amsterdam.) 3rd edition. Kampen: Kok.

Letter to Diognetus. 1885, tr. Roberts, A. and J. Donaldson, J. AnteNicene Fathers 1.

Buffalo, NY: Christian Literature.

Origen. 1885. Contra Celsus, tr. Crombie, F. AnteNicene Fathers 4. Buffalo, NY: Christian Literature.

Origen. Commentary on Matthew, JP. Migne, Patrologia Graeca 13: 855 - 1600. Rahner, H. 1961. Kirche und Staat im frühen Christentum. Dokumente aus acht Jahrhunderten und ihre Deutung. München: Kösel.

Tertullian. 1885. The Chaplet, tr. Thelwall, S. AnteNicene Fathers 3. Buffalo, NY: Christian Literature. Traditio Apostolica. La Tradition Apostolique d'après les Anciennes Versions, 2nd edition. 1984. Sources Chrétiennes 11 bis. Paris: Cerf.

Van de Beek, A. 2006. Onward Christian Soldiers! Christians in the Army. Acta Theologica 26(1), 159 - 179.

\section{KEY WORDS}

Reformed theology

Political involvement

Early Christianity

Calvin

Karl Barth

\section{KERNWOORDE}

Gerefromeerde teologie

Politieke betrokkenheid

Vroeë Christendom

Calvyn

Karl Barth

Prof. Bram van de Beek

Petenbos 8, 3904 BN

Veenendaal,

The Netherlands.

beekavd@xs4all.nl 